\title{
O estrangeiro aprendera a falar a língua do imperador... A lógica do traçado
}

\section{The foreigner had learned to speak the language of the emperor... The logic of the trace}

\author{
Rosilene Beatriz Machado ${ }^{1}$ \\ Cláudia Regina Flores ${ }^{2}$
}

\section{Resumo}

Este artigo intenta analisar como saberes em desenho e matemática são mobilizados em tratados militares, especificamente, nas obras: Tratado sobre a Fortificação de Cidades, Fortalezas e Vilas (1527), escrito por Albrecht Dürer; Methodo Lusitanico de Desenho de Fortificaçoens das Praças Regulares e Irregulares (1680), de autoria de Luís Serrão Pimentel; e O Engenheiro Portuguez: dividido em dous tratados (1728), de autoria de Manoel de Azevedo Fortes. Isso porque, dando a ver e falar determinado discurso, esses textos funcionam como dispositivos de enunciação que contribuíram à constituição e difusão do desenho e da matemática enquanto saberes a ensinar. O que implica, ademais, um alargamento da compreensão de que esses saberes não devem ser desvinculados de práticas sociais; que foram essas práticas que elegeram seus conteúdos como objeto de ensino; e que foram esses conteúdos, posteriormente, que compuseram os currículos escolares.

Palavras-chave: Desenho; Matemática; História; História da Educação.

\begin{abstract}
This article tries to analyze how knowledge in drawing and mathematics is mobilized in military treaties, specifically in the works: Treaty on the Fortification of Cities, Strengths and Villages (1527), written by Albrecht Dürer; Methodus Lusitanico of Drawing of Fortifications of the Regular and Irregular Squares (1680), by Luis Serrão Pimentel; And The Portuguese Engineer: divided into two treatises (1728), authored by Manoel de Azevedo Fortes. This is because, given to see and speak a certain discourse, these texts function as devices of enunciation that contributed to the constitution and diffusion of drawing and mathematics as knowledge to teach. What implies, in addition, an extension of the understanding that these knowledge should not be separated from social practices; That it was these practices that chose their contents as an object of teaching; And that it was these contents that later composed the school curricula.
\end{abstract}

Keywords: Drawing; Mathematics; History; History of Education.

\section{Submetido em: 22/07/2017 - Aceito em: 18/07/2018 - Publicado em: 19/07/2018}

1 Doutora em Educação Científica e Tecnológica pela Universidade Federal de Santa Catarina (UFSC). Professora do Departamento de Metodologia de Ensino do Centro de Ciências da Educação da UFSC, Brasil. Email: rosilene.machado@ufsc.br.

${ }^{2}$ Doutora em Educação pela Universidade Federal de Santa Catarina (UFSC). Professora do Departamento de Metodologia de Ensino do Centro de Ciências da Educação da UFSC, Brasil; credenciada no Programa de PósGraduação em Educação Científica e Tecnológica (PPGECT/UFSC). Líder do Grupo de Estudos Contemporâneos e Educação Matemática (GECEM), criado em 2009. Pesquisador Produtividade CNPq. Email: claudia.flores@ufsc.br. 


\section{Introdução}

DOI: http://dx.doi.org/10.20396/zet.v26i3.8649929

Os séculos XVII e XVIII, em especial, foram marcados pelo florescimento de instituições que se voltaram para a formação exclusiva do engenheiro militar. Especificamente em Portugal, foram criadas aulas régias intituladas Aula de Fortificação e Arquitectura Militar, instituídas em 1647, diante do cenário de guerra contra a Espanha e de restabelecimento do trono, a fim de suprir a dependência de profissionais estrangeiros extremamente onerosos para o país. Seu modelo foi transplantado para os principais centros urbanos das províncias portuguesas através das Aulas de Arquitetura Militar ou Aula de Fortificações. No Brasil, destacam-se as Aulas instituídas nas províncias da Bahia (1696), Rio de Janeiro (1699), e Pernambuco (1701). Em 1738 o ensino militar tornou-se obrigatório a todo oficial no território brasileiro de forma que, a partir daí, os militares só poderiam ser nomeados caso tivessem aprovação na Aula de Artilharia e Fortificações, curso regular e obrigatório que se instalava no país, e cujo objetivo era formar engenheiros militares habilitados a construir fortificações com vistas à defesa do território nacional.

Em 1792 foi criada a Real Academia de Artilharia, Fortificação e Desenho (espelhando sua congênere portuguesa criada dois anos antes, a Academia Real de Fortificação, Artilharia e Desenho de Lisboa), e em 1795 foi criada a Nova Academia de Aritmética, Geometria Prática, Fortificação, Desenho e Língua Francesa para os Oficiais de Infantaria. Pouco mais de dez anos depois, a chegada da corte portuguesa ao país provocaria significativas mudanças no ensino através da instituição da Academia Real dos Guarda Marinha, em 1808, e da criação da Academia Real Militar em 1811, que substituiu a Real Academia de Artilharia, Fortificação e Desenho. A Academia Militar destinava-se, conforme Carta de Lei de 1810, ao ensino das ciências exatas e da engenharia em geral, no sentido mais amplo da sua época, formando não só oficiais de engenharia e de artilharia, assim como geógrafos e topógrafos que pudessem trabalhar em minas, caminhos, portos, canais, pontes, fontes e calçadas. Para essa formação, os alunos teriam um curso completo de ciências matemáticas e aprenderiam física, química, mineralogia, metalurgia e história natural, além do aprendizado das ciências militares. Isso porque:

Em Portugal e no Brasil, na ausência de arquitetos, os engenheiros executaram não apenas obras militares, como também civis, religiosas e de infraestrutura urbana (...). Além disso foram, em geral, os autores dos projetos da maioria das novas vilas e cidades fundadas oficialmente pela Coroa, e responsáveis pelo mapeamento do território. É comprovada a presença de 247 engenheiros militares atuantes no Brasil, entre 1500 e 1822 (Bueno, 2011, p. 137).

Esse conjunto de atividades foi mediado pelo desenho em todas as suas etapas, do planejamento, orientação e supervisão, à prestação de contas ao rei. Muito provavelmente os desenhos eram produzidos em mais de uma via, de forma que uma fosse direcionada aos canteiros de obra para conduzir o trabalho de construção e outra aos conselhos de guerra do Reino. Gradativamente, esse conhecimento em desenho deixou de ter sua presença restrita aos espaços militares, inserindo-se no meio escolar, primário e secundário, ao longo de sua instituição. Claro que sob um intricado e complexo processo, mas, ainda assim, possibilitado 
DOI: http://dx.doi.org/10.20396/zet.v26i3.8649929

em grande medida pelos professores militares convocados para tal ensino e por meio dos manuscritos e tratados advindos de sua experiência profissional. O que os torna [os tratados militares], portanto, um dos principais mecanismos de propagação do desenho e da matemática no meio escolar elementar. E que nos coloca a perceber, assim, que conhecimentos por eles circularam; conhecimentos que constituiriam os conteúdos escolares dessas disciplinas no bojo de sua institucionalização na esfera pública brasileira.

Mais que isso, uma vez que esses tratados aludiam, prioritariamente, a questões relativas à "arte de bem fortificar", torna-se fundamental questionar: Que saberes em desenho e matemática tornaram possível a representação do espaço e/ou de determinado território? Que conceitos eram requeridos afim de que se pudesse representar no papel uma fortificação ou cidade (quer fosse real ou ideal)? Que ensinamentos, afinal, foram postos em circulação por esses dispositivos e que apropriações, a partir deles, foram então efetivadas pela escola?

Disso, o presente artigo tem por objetivo analisar três significativos tratados militares $^{3}$ : Tratado sobre a Fortificação de Cidades, Fortalezas e Vilas (1527), escrito por Albrecht Dürer; Methodo Lusitanico de Desenho de Fortificaçoens das Praças Regulares e Irregulares (1680), de autoria de Luís Serrão Pimentel; e O Engenheiro Portuguez: dividido em dous tratados (1728), de autoria de Manoel de Azevedo Fortes ${ }^{4}$. O tratado sobre fortificações do gravador e pintor alemão Albrecht Dürer é a primeira obra impressa sobre fortificação militar, tendo constituído referência para muitos trabalhos produzidos nesse âmbito nos séculos seguintes. A obra de Luís Serrão Pimentel ${ }^{5}$, por sua vez, é a primeira publicação em território português acerca da construção de fortificações fazendo parte, durante relevante período, juntamente com o tratado de Azevedo Fortes ${ }^{6}$, das principais bibliografias utilizadas nas Aulas de Fortificação e Academias Militares existentes no Brasil (Bueno, 2011; Doria, 2004; Trinchão, 2008). Dessa forma, os referidos tratados caracterizaram-se em consideráveis dispositivos ${ }^{7}$ de enunciação que, dando a ver e falar

\footnotetext{
${ }^{3}$ As análises aqui apresentadas são oriundas do trabalho de tese intitulado: Cartografia, Saber, Poder: Da emergência do desenho como disciplina escolar. Ver Machado (2016).

${ }^{4}$ Nas análises a seguir, as transcrições de trechos das duas últimas obras destacadas serão feitas tais quais sua publicação, ou seja, sem alterações para a forma atual de escrita da língua portuguesa.

5 Tenente-General, Cosmógrafo-Mor e Engenheiro-Mor do Reino Português, além de primeiro lente catedrático da Aula de Fortificação e Arquitectura Militar de Lisboa.

${ }^{6}$ Acadêmico da Academia Real da História Portuguesa, cavalheiro e professor da Ordem de Cristo, brigadeiro de Infantaria dos Exércitos Reais e Engenheiro-Mor do Reino de Portugal -, desenvolveu sua obra com o fim de servir-lhe à própria instrução, passando-a depois em método aos praticantes da Academia Militar.

${ }^{7}$ Utiliza-se aqui o termo dispositivo com base em Foucault, entendendo-o "como um conjunto decididamente heterogêneo que engloba discursos, instituições, organizações arquitetônicas, decisões regulamentares, leis, medidas administrativas, enunciados científicos, proposições filosóficas, morais, filantrópicas. Em suma, o dito e o não dito são os elementos do dispositivo. O dispositivo é a rede que se pode estabelecer entre estes elementos" (Foucault, 2010, p. 244).
} 
DOI: http://dx.doi.org/10.20396/zet.v26i3.8649929

determinado discurso sobre o desenho e a matemática, contribuíram para sua constituição e difusão enquanto saber a ensinar ${ }^{8}$.

\section{Da lógica do traçado}

Pois bem. Quiçá o enunciado primeiro que se possa extrair de tais textos seja: desenhar é proteger. Ora, quanto melhor construída for uma fortificação, mais seguro de ataques inimigos estará o território considerado; e serão o desenho e a matemática que garantirão o êxito dessa empreitada. Senão vejamos.

O pequeno tratado alemão, com pouco menos de 80 páginas, publicado em 1527 e dedicado a Fernando I, rei da Hungria e da Bohemia, presta-se a "refletir sobre como deve ser construída uma fortificação em que se possa proteger reis, príncipes, senhores e cidades" (Dürer, 2004, p. 117, tradução nossa). Trata tanto do assentamento de fortalezas e cidades de nova fundação como de antigas construções, podendo ser dividido em quatro partes.

A primeira, que ocupa mais da metade do tratado, aborda a construção de bastiões para a defesa de grandes cidades, detalhando-se seu delineamento. O bastião tem por função suportar o "grosso" da defesa de uma cidade amuralhada, comportando as canhoneiras; é uma construção de planta semicircular, podendo ser erigida, de acordo com Dürer, de três maneiras distintas. Tal distinção não diz respeito à forma - já que sempre se mantém uma planta comum que consiste em um retângulo anteposto a uma frente curvada -, mas sim às dimensões e sua construção interna.

Pode-se dizer que essa discussão inicial, ressalte-se - mais uma vez -, que ocupa a maior parte do livro, é também a mais densa. É aí que o efetivo traçado de construções arquitetônicas é abordado. E é ela que particularmente interessa aqui no sentido de compreender como o desenho fez-se suporte de toda essa elaboração. Analisemos como a descrição geral da primeira maneira de construir um bastião é apresentada:

Primeiro desenha-se sobre um terreno plano com duas linhas A e C a forma da esquina da muralha urbana onde se quer construir o bastião. No ponto em que essas linhas definem um ângulo marca-se B. Depois corta-se o ângulo B com uma reta de 300 pés e se marcam seus extremos com $\mathrm{D}$ e $\mathrm{E}$, de modo que $\mathrm{DB}$ e $\mathrm{BE}$ tenham o mesmo comprimento, como se ilustra adiante (...).

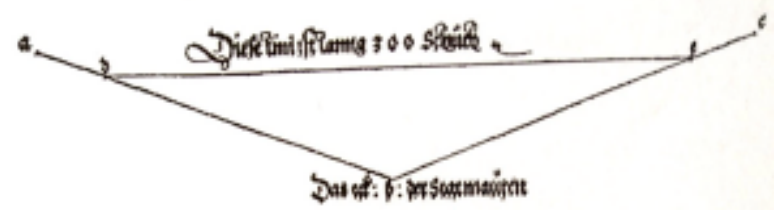

Figura 1 - Ilustração do procedimento descrito por Dürer.

Fonte: Dürer (2004, p. 119).

\footnotetext{
${ }^{8}$ Não há uma nítida separação nesses tratados entre conhecimentos em desenho e matemática, compreendendo aí uma espécie de "desenho matematizado" ou "geometria prática". Assim, ainda que nas análises que seguem a ênfase recaia sobre o desenho, entenda-se que a matemática está contemplada nos termos que aqui destacamos.
} 
Depois se traça uma bissetriz FG que corte ao meio a linha DE e o ângulo B, de maneira que DE e FG definam quatro ângulos iguais e $\mathrm{G}$ esteja situado no fosso ${ }^{9}$. O ponto de intersecção dos quatro ângulos é H. Então se coloca sobre a linha HG um ponto I a 90 pés de distância de H. Em seguida, coloca-se um compasso com um braço sobre a linha $\mathrm{FH}$ em um ponto $\mathrm{K}$, que se deve encontrar, e se descreve com o outro braço uma linha circular DIE. Esta representa em planta a curvatura do bastião sobre o fosso. Agora se deve retrair sua gola ${ }^{10}$ à cidade até uma profundidade equivalente à área diante da linha DE (...). Traçar-se-á um retângulo de 60 pés de fundo a partir da linha DE e cujas esquinas sejam L e M. Com estas linhas já está completamente finalizada a base do bastião. (...) Mas antes de prosseguir quero representar, por meio das referidas linhas, a planta desta base com a gola dentro da cidade (Dürer, 2004, p. 118-119, tradução nossa).

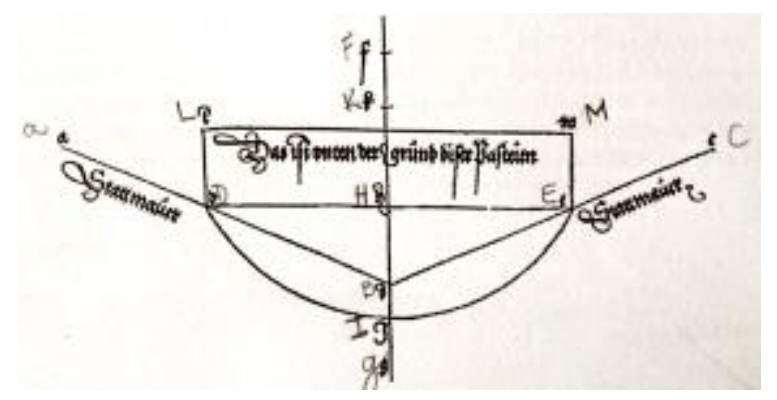

Figura $2^{11}$ - Ilustração do procedimento descrito por Dürer. Fonte: Dürer (2004, p. 119).

Descrito o processo de construção da base, Dürer trata da feitura dos muros, da plataforma de defesa pirobalística e dos demais elementos constituintes de um bastião. A figura a seguir mostra a planta finalizada da construção à primeira maneira:

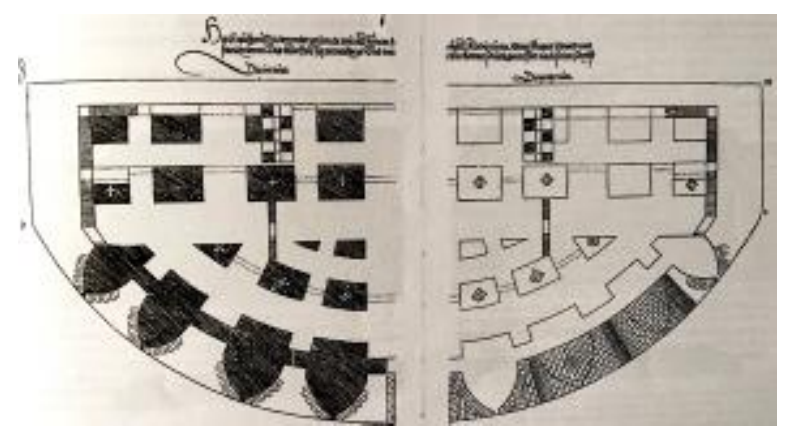

Figura 3 - Planta do bastião descrito por Dürer.

Fonte: Dürer (2004, p. 140-141).

\footnotetext{
${ }^{9}$ Escavação profunda, podendo ser seca ou cheia de água, que geralmente circunda as obras de fortificação com o intuito de proteger a fortaleza e dificultar seu acesso.

${ }^{10}$ Parte posterior do bastião que o liga ao resto da fortaleza.

11 Para que se possa acompanhar melhor o processo descrito, inseriu-se na imagem, ao lado de cada letra indicada por Dürer, sua ortografia em língua portuguesa atual.
} 
De forma análoga, as duas demais formas de levantar um bastião são explicadas. E nesse processo o que se percebe é que tudo precisa ser minuciosamente calculado, projetado; garantir a máxima eficácia defensiva de uma fortificação implica pensá-la e representá-la com precisão. Nesse jogo, o desenho cumpre papel decisivo: é responsável pela mediação entre os aspectos práticos e teóricos, entre o real e o abstrato; dialoga com a escrita e, ao fazêlo, permite ver. Por meio do desenho garante-se, então, a ordem sobre a terra, a demarcação do espaço, o êxito da construção e, com isso, a pretendida proteção desses domínios.

As partes restantes do tratado são bastante sucintas. Na segunda, contendo apenas 12 páginas, o autor discorre sobre a situação, localização e distribuição de uma cidade fortificada. Isto para "o caso de que um senhor tenha um território vasto e bem situado e a possibilidade de construir a seu gosto uma cidade fortificada em que habitar e defender-se de seus inimigos" (Dürer, 2004, p. 151, tradução nossa). Trata, portanto, do condicionamento topográfico, assentamento e distribuição interna de uma cidade fortificada de nova fundação, apresentando sua concepção de cidade ideal, totalmente quadrangular, com explícita inspiração vitruviana. A indicação é de que no centro deveria localizar-se a casa do rei e a seu redor o tecido urbano, disposto em ruas conformadas por um padrão ortogonal cruciforme, de maneira que a população ficasse distribuída hierárquica e utilitariamente.

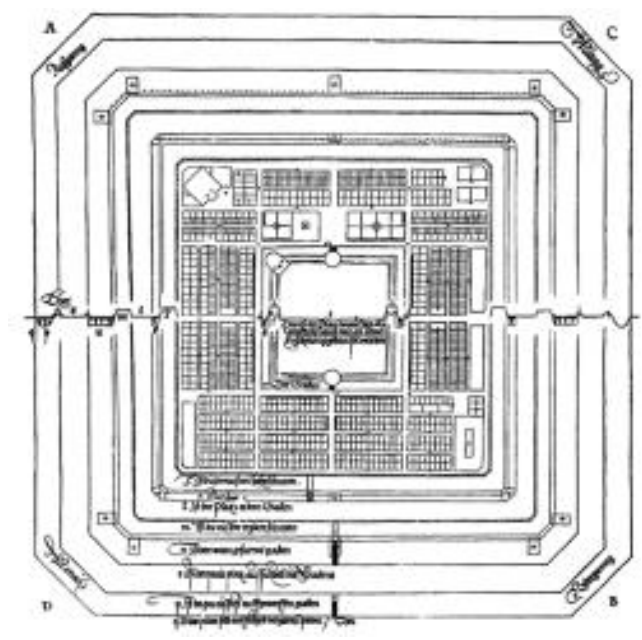

Figura 4 - Cidade ideal de Albrecht Dürer.

Fonte: Dürer (2004).

Já a terceira parte, contendo 10 páginas, aborda a descrição de uma fortaleza circular de bloqueio. Refere-se ao desenho e alinhamento de uma fortaleza de base circular assentada em uma área localizada entre uma grande massa de água e uma elevação de terreno, ou seja, entre uma grande parede rochosa ou uma montanha de um lado e uma grande extensão de água ou até mesmo o mar de outro - elementos naturais que serviriam de bloqueio ao inimigo. Por fim, em três breves páginas são tecidas algumas considerações sobre a fortificação de uma vila ou cidade de antiga fundação. Para essa situação, Dürer sugere a construção de fossos mais profundos e grossos muros de pedra que pudessem tornála mais resistente a invasões e ataques externos. 
DOI: http://dx.doi.org/10.20396/zet.v26i3.8649929

O Methodo Lusitanico, de Luís Serrão Pimentel, por outro lado, é uma obra extensa, contendo 842 páginas, e dividida em duas partes. A primeira, chamada Operativa, em que o autor explica seu método, está também dividida em duas seções: uma do desenho dos lados dos polígonos exteriores para dentro; outra dos polígonos interiores para fora. A premissa é de que a partir do desenho de polígonos, e de proporções, é possível enquadrar regularmente quaisquer tipo de terrenos, regulares ou não. A segunda parte, Qualitativa, busca demonstrar através de provas e demonstrações as operações realizadas na primeira. Ao final, há ainda dois apêndices de comentários sobre as obras do Conde de Pagan, e mais dois compêndios intitulados Trigonometria Practica Rectilinea e Compendio de Alguns Problemas de Geometria practica e Theoremas da especulativa.

O conteúdo é desenvolvido, em geral, através de questões práticas a serem conduzidas no campo de fortificação, sempre acompanhadas por figuras que dão a ver e compreender os cálculos e construções empreendidas. É assim que Pimentel vai expondo seu "facílimo" método de desenhar as fortificações, e os conhecimentos em desenho e matemática vão sendo expostos e requeridos.

Entretanto, vale sublinhar que há uma diferença fundamental na organização desse tratado se comparado com o de Albrecht Dürer. Enquanto o tratadista alemão dá por subentendido o conhecimento de saberes em desenho ${ }^{12}$, utilizando-os sem maiores explicações nas construções que apresenta, Pimentel dedica uma discussão detalhada dos principais conceitos e procedimentos de desenho necessários para bem fortificar. Assim, saberes específicos não são só requisitados e utilizados, mas antes explicados no desenrolar da obra. Os três capítulos iniciais da Seção I, parte I, por exemplo, tratam pontualmente da definição de ângulo e suas medidas. A título de ilustração, vejamos como o autor, no capítulo I, define Que cousa seja Angulo plano rectilineo: "Angulo plano rectilineo [que he o de que trattamos, \& entra no uso da Architectura militar] segundo Euclides he a inclinaçaõ de duas linhas rectas que reciprocamente se tocaõ, \& naõ jazem em direito" (Pimentel, 1680, p. 1). No que segue com um exemplo:

$A$ inclinaçaõ que a linha $A B$ tem para a linha $C B$ ou $C B$ para $A B$ tocandose reciprocamente no ponto $\mathrm{B}, \&$ naõ jazendo em direito huma da outra he o angulo ABC. Quando se poem tres letras para explicaçaõ de hum angulo, sempre a de meyo he a que o denota.

Esta inclinaçaõ que huma linha tem a outra pode ser mayor, ou menor, daqui resultar mayor, ou menor angulo, a saber mais, ou menos aberto.

Para se medir pois o valor de cada angulo se valeraõ industriosamente os Geometras da circunferencia de hum circulo que lhe servisse de medida; \& para mais clara intelligencia se deve saber que por antiquissimo uzo, \& convenientes razoens [que havemos apontado no Capitulo primeiro da practica da Trigonometria rectilinea] se

\footnotetext{
${ }^{12}$ No sentido de que não se dedicam seções especiais ou problemas específicos para tratar de seus conceitos. No processo indicado pela figura 2, por exemplo, parece já dado, ou subentendido, o conceito de bissetriz, assim como o cálculo do ponto K. Perceba-se que para encontrar este ponto é preciso remeter-se a um teorema de geometria euclidiana, segundo o qual por três pontos não colineares só pode passar uma única circunferência. Seu centro é obtido traçando-se duas retas imaginárias DI e IE secantes em I, cujas paralelas se cortam no ponto $\mathrm{K}$ procurado.
} 
DOI: http://dx.doi.org/10.20396/zet.v26i3.8649929

divide a circunferencia de qualquer circulo grande, ou pequeno como $\mathrm{ABCD}$ em 360 partes iguaes, a que chamaõ gráos, \& cada huma dessas partes, ou gráo em 60 particulas mais miudas que se dizem segundos, $\&$ assim foraõ continuando pordiante com divisaõ sexagenaria em terceiros, quartos, quintos, \&c. o que tem seu uzo na Astronomia. Na figura senaõ mostra a divisaõ grao por gráo pella brevidade do espaço.

Isto suposto, Para se saber o valor de cada angulo como por exemplo FHE se poem o pé do compasso no ponto $\mathrm{H}$ onde concorrem as linhas, \& delle como de centro se descreve a qualquer distancia a circunferencua GFE, \& quantos gráos, ou gráos, \& minutos tiver o arco FE entre as linhas que formaõ o angulo, de tantos se diz ser este, ou o seu valor.

Para isto se medir practicamente se faz hum semicirculo de lataõ graduado, ou melhor de lamina das que se poem nas lanternas por ser transparente; cujo centro applicado ao ponto $\mathrm{H} \&$ estendidas as linhas até a circunferencia graduada apontaõ na graduaçaõ do semicirculo os gráos, ou os gráos \& minutos, que se incluem entre as linhas, que formaõ o angulo, \& mostrã̃ seu valor. (...) (Pimentel, 1680, p. 1-2).
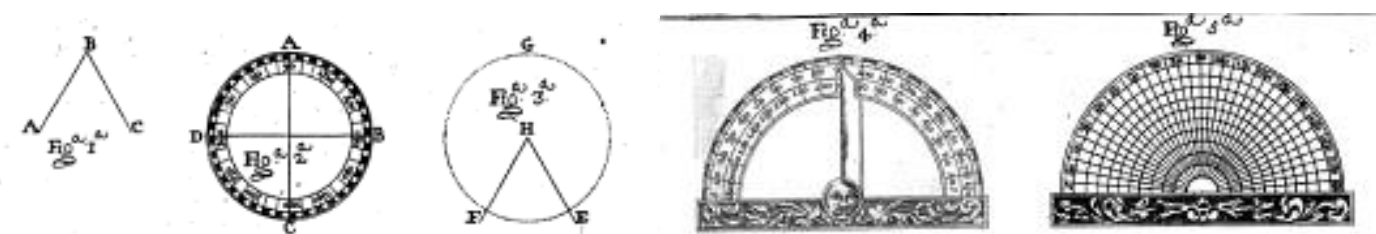

Figura 5 - Figuras 1, 2, 3, 4, 5 referentes ao Cap. I da seção I do Methodo Lusitanico. Fonte: Pimentel (1680, p. 16-17).

Ou, no capítulo IV, como Descrever no papel qualquer Polygono regular até o de 20 lados:

(...) Tomese com o compasso em qualquer dellas [das linhas que se veem na figura 10] a distancia do ponto A seu principio até o ponto sinalado com o numero $6 \& \mathrm{com}$ elle assim aberto se descreva hum circulo DFCNH o qual descripto, se quizermos fazer uma figura de 5 lados, tomaremos a distancia entre o ponto A \& o numero 5 \& com o compasso assim aberto apontaremos espaços na circunferencia, que se acharaõ 5 iguaes. Lançando pois de ponto a ponto cinco linhas, formaraõ a figura regular de 5 lados (Pimentel, 1680, p. 7).

Pimentel afirma que este é o procedimento que deve ser seguido para a construção de qualquer figura regular de até 20 lados, argumentando que não traz padrões para figuras maiores porque estas dificilmente seriam aplicáveis na construção de fortificações. Uma vez deslindados, é que esses conhecimentos poderão, pois, ser utilizados em questões práticas, tal como no capítulo XII dessa mesma seção I, em que se trata Do modo com que se desenhã̃ practicamente os Polygonos regulares no terreno. Para desenvolvê-la, vai-se fazendo referência a explicações anteriores: "Considerado o sitio em que convem ficarem situados os angulos flanqueados dos Baluartes, \& permittindo formarse figura regular se forme com o instrumento, ou com a fitta gradual descripta no Capitulo 5. pelo modo que se disse no Capítulo 6. hum angulo (...)" (Pimentel, 1680, p. 40-41, grifos nossos). Também como no 
DOI: http://dx.doi.org/10.20396/zet.v26i3.8649929

capítulo XIV, em que se explica Como se devem desenhar na Cãpanha os Fortes e Praças regulares por huma facíllima práctica, \& bem apurada proporção de invento próprio:

Desenhando no terreno o Polygono exterior segundo a doutrina do Capítulo 2, que seja por exemplo o Quadrado ABCD cujos angulos se devem accomodar onde querem que fiquem os Baluartes, se tome a quarta parte de cada lado do Polygono, a saber $\mathrm{BH}, \mathrm{AL}$, para cada huma das sobre-faces. Dos pontos $\mathrm{L}, \mathrm{H}$ se levantem sobre $\mathrm{AB}$ as perpendiculares LI, HF que sirviràõ de Flancos prolongados; \& logo diremos de que medida conforme for a figura. Do ponto I até F se lançará a cortina IF. Dos Flancos prolongados LI, HF se cortem as Extensoens dos Flancos LO, HE, que também se dirá de que quantidade conforme a figura; \& do ponto $\mathrm{A}$ até $\mathrm{O}$ de $\mathrm{B}$ até $\mathrm{E}$ se lancem as Faces AO, BE, \& os Flancos seraõ OI, EF. Semelhantemente se obre com os mais lados do Polygono exterior para se acabarem de formar os Baluartes, \& Cortinas, com as proporçoes seguintes (...) (Pimentel, 1680, p. 47-48).

A figura abaixo ilustra o processo de construção:

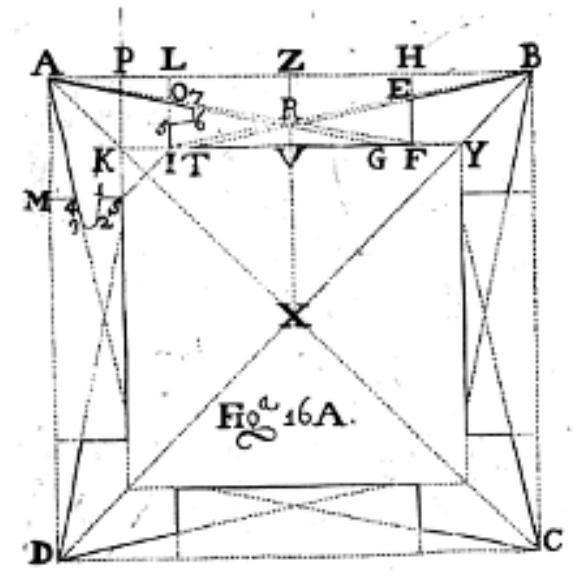

Figura 6 - Construção de um forte segundo o método de Luís Serrão Pimentel.

Fonte: Pimentel (1680, p. 17).

Não se tem no Methodo Lusitânico, desse modo, somente um tratado sobre fortificação, mas também uma espécie de compêndio de desenho, ligado a questões práticas. Tal forma de organização está, atente-se, perfeitamente conforme às advertências realizadas pelo autor em seu proêmio:

A disposição desta obra he que proponho em primeiro lugar hua facillima practica, tal que por ella saberà qualquer soldado facillima, \& brevissimamente desenhar todo $\mathrm{o}$ genero de Fortificaçoens, que hoje se practicaõ, com proporçoens apuradissimas, das quaes resultaõ aquellas naõ somente defensivas, \& offensivas com todo o militar primor, mas cada hua em sua especie, \& segundo sua grandeza solidamente robustas, sem que lhe seja necessário saber Geometria, nem Arithmetica, mais que multiplicar, $\&$ repartir por hua, ou duas letras para o desenho, que he em que consiste o acerto, ou erro da obra (Pimentel, 1680, p. XIII, grifos nossos).

O desenho é o que assegurará o acerto ou erro da obra; é esse saber, por conseguinte, que precisará ser vigorosamente elucidado. E, de fato, Pimentel o coloca em movimento no desenvolvimento de todo o texto. Por exemplo, no capítulo IX, seção II, parte I, intitulado Do desenho para se fabricarem os arcos de pedraria, assim de volta circular, como abatidos, e de sua mediçã̃, uma ampla análise sobre elipses e esferoides - desde sua 
DOI: http://dx.doi.org/10.20396/zet.v26i3.8649929

construção até a medida de perímetro, área e volume - é apresentada. No compêndio sobre trigonometria retilínea, um estudo completo sobre triângulos e figuras regulares e irregulares é exposto. No compêndio sobre geometria prática, igualmente o desenho está fortemente destacado, trabalhando-se toda a parte de definição e construção de retas paralelas e perpendiculares, meia proporcional, divisão de ângulos e arcos, construção de círculos, delineação de figuras regulares, ampliação e redução de figuras, e equivalência de áreas e volume.

Merece atenção, ainda, o item destinado ao modo de representar no papel uma fortificação, presente no capítulo VI, seção II, parte I - Do modo de relevar huma planta para que represente a Fortificaçaõ levantada sobre o terreno. Nele, explica-se como construir a representação requerida através da perspectiva militar, alegando-se ser esta melhor que a perspectiva rigorosa (ou linear) por não alterar as medidas da obra. $\mathrm{O}$ procedimento é assim indicado:

(...) Isto suposto seja a linha Ichonographica de uma Planta abcdefg, \&c. Lancese da parte de que mais queremos mostrar o relevo uma linha horizontal $A B$ de qualquer modo que se lãce; pois sempre podemos imaginar que a representa.

De todos os angulos da figura formados pella Ichonographica se deitem perpendiculares à ditta linha horizõtal (excepto daqueles, donde vindo as taes perpendiculares passaõ por cima dos Parapeitos, \& Terraplenos) quaes se mostraõ pellas de pontinhos: nestas se tome huma altura que se supponha ser a da muralha desde o plano do Fosso como bh, que suponhamos ser de 36 pés: outro tanto as alturas al, yi, zm, xn, uo, tp, sq, rc \& c. Lancemse as linhas hl, li, mn, no \& c a distancia entre estas, e a linha Ichonographica representa a altura da muralha, ou Terrapleno (...) (Pimentel, 1680, p. 235-236).

A figura a seguir ilustra a operação:

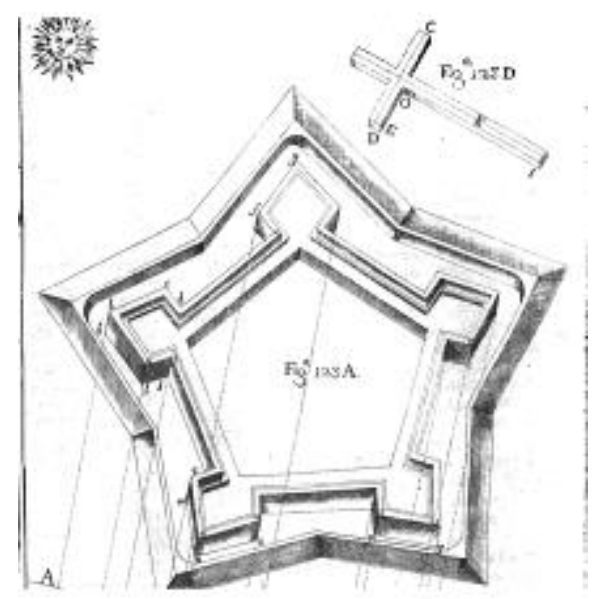

Figura 7 - Representação em relevo de uma fortificação. Fonte: Pimentel (1680, p. 238).

O desenho, destarte, precisa ser operado tanto para a projeção das construções quanto para a sua representação. Esses são conhecimentos tornados imprescindíveis para o engenheiro militar em seu ofício. Somente de posse deles é que será possível fortificar e 
DOI: http://dx.doi.org/10.20396/zet.v26i3.8649929

representar vilas e cidades. Todos os problemas práticos ligados à arte de bem fortificar prescindem do conhecimento em desenho. Fortificar pelo método de Pimentel requer do engenheiro, portanto, que saiba traçar polígonos, dividi-los, medir seus ângulos, construir retas paralelas e perpendiculares, enfim, requer reais habilidades na técnica do desenho. Esse saber configura-se, assim, em um procedimento de precisão que, mais que se restringir a uma técnica de registro, possibilita evitar erros; um mecanismo de projeção que tem o poder de desenvolver uma ideia e materializá-la com justa perfeição por meio de informações rigorosas e exatas, tal como é possível perceber nas figuras a seguir:

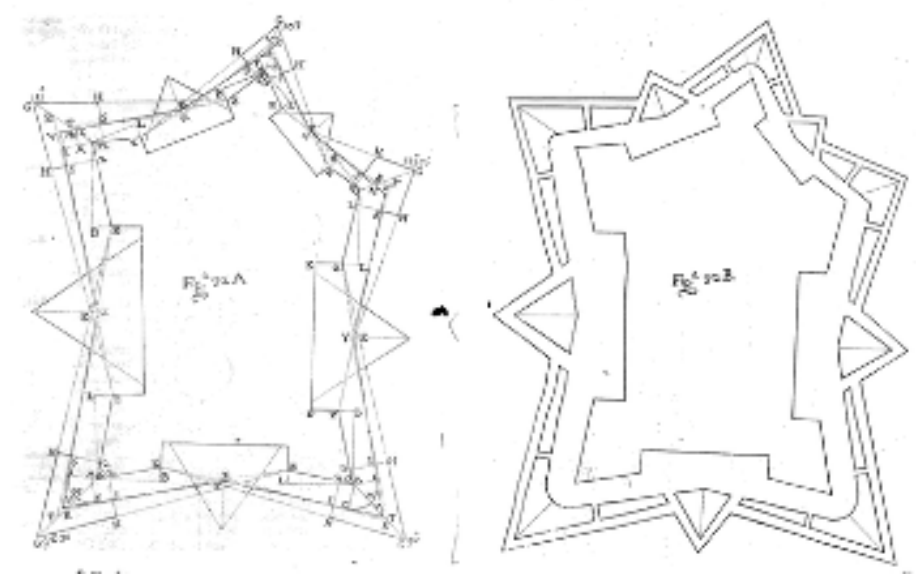

Figura 8 - Traçado dos fossos de uma fortificação irregular (à esquerda) e planta final (à direita). Fonte: Pimentel (1680, p. 74-75).

Esse estatuto conferido ao desenho pode, da mesma forma, ser observado nO Engenheiro Portuguez, de Manoel de Azevedo Fortes. A obra está dividida em dois tratados: o Tomo I, que trata da geometria prática sobre o papel e sobre o terreno; o uso dos instrumentos mais necessários aos engenheiros; e o modo de desenhar e dar aguadas nas plantas militares; contendo ainda um apêndice de trigonometria retilínea; e o Tomo II, que compreende a fortificação regular e irregular; e o ataque e defesa das praças; além do apêndice que contempla o uso das armas de guerra.

Nesses tratados, segundo o autor, procurou-se dar "uma nova luz à matéria", fazendoa "inteiramente perceptível" através de figuras apresentadas nas estampas (presentes no final da obra) e de exemplos conhecidos. Fortes afirma também, ainda no prólogo, que da primeira parte não havia nada impresso em português, e que da segunda também havia pouco, ou nada, já que pouquíssimos exemplares do Método Lusitânico, de Luis Serrão Pimentel, encontravam-se em circulação.

O primeiro tratado, da geometria prática, está subdividido em três livros: da longimetria - em que se ensina a medir distâncias acessíveis e inacessíveis sobre a terra, com e sem instrumentos; da planimetria - em que se ensina a medir superfícies; e da estereometria - em que se tratam das medições de corpos regulares e irregulares. Além, como indicado, do apêndice de trigonometria retilínea em que se aborda o cálculo de distâncias inacessíveis. 
DOI: http://dx.doi.org/10.20396/zet.v26i3.8649929

Nos cinco primeiros capítulos do Livro I, da longimetria, trata-se das definições de ponto, reta, e medida de comprimento, bem como da conceituação de números geométricos e suas operações, para, nos capítulos seguintes, aplicá-los a problemas necessários da geometria prática, de construção, medida e divisão de retas, ângulos, círculos e seus elementos, e localização do centro de polígonos. O Problema VI, do capítulo VI, por exemplo, intitulado Descrever hum circulo sobre a superfice da terra, assim é exposto:

Os circulos sobre o papel, ou sobre superfices curtas se descrevem com o compaço: mas para superfices de maior extençaõ, como sobre a terra, se descrevem por meio de hum cordel, na forma seguinte. No ponto que se determina para centro do circulo, se prega uma estaca delgada, ou hum prego, sendo o terreno duro, e o extremo do cordel terá uma laçada, ou nó aberto, para se meter na estaca. e poder andar à roda sem se entortilhar, e com outro extremo do cordel, estendido do comprimento, que deve ter o semidiametro, se irá descrevendo o circulo, finalizando a linha curva ou circunferencia sobre a terra. (...) Do mesmo modo se descreverá qualquer segmento, ou porçaõ do circulo (Fortes, 1728, p. 40).

No Problema VII, por sua vez, ensina-se a Achar o diametro e o centro de hum circulo dado:

(...) Seja o circulo sobre o papel, ou sobre a terra $A B C$, do qual queremos saber o diametro: lance-se huma linha qualquer $\mathrm{AB}$ dentro do circulo, e terminada na circunferencia; divida-se pelo meio no ponto D (Problema II) e sobre ella do ponto D se levante a perpendicular EDC, e será esta o diametro buscado: e para saber o centro divida-se pelo meio, \&c. (...) (Fortes, 1728, p. 40-41).

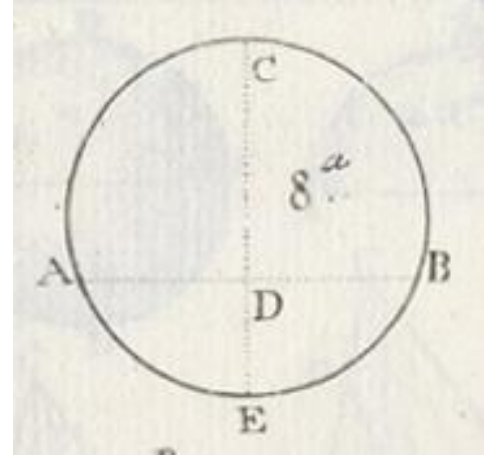

Figura 9 - Traçado de centro e diâmetro de círculo dado.

Fonte: Fortes (1728, p. 541).

Já no Livro II, da planimetria, desenvolve-se um estudo completo nos nove primeiros capítulos acerca das definições, medida e divisão de superfície de círculo, setor circular, segmento circular, elipse, parábola, hipérbole, triângulos, paralelogramos, quadrados, trapézios e polígonos em geral, para, no capítulo X, Da Divizaõ dos Campos chamada Geodezia, voltar-se à aplicação prática desses conceitos no campo. No Problema II, por exemplo, o autor trata de Dividir hum campo triangular em qualquer numero de partes iguaes por linhas lançadas de hum ponto dado em hum dos seus lados:

Se do ponto dado se lançar uma linha recta ao angulo opposto, e o mesmo lado se dividir nas partes iguaes pedidas, e dos pontos das divizões se lançarem linhas parallelas à primeira, e dos pontos em que as parallelas cortarem os outros dous lados, 
DOI: http://dx.doi.org/10.20396/zet.v26i3.8649929

se lançarem linhas rectas ao ponto dado, estas dividiraõ a terra nas partes iguaes pedidas.

Suponhamos, por exemplo, o campo triangular $\mathrm{ABC}$, que se quer dividir em tres partes iguaes, e que as divizões nasçaõ do ponto $\mathrm{D}$, tomado no lado $\mathrm{AB}$. Lance-se do ponto $\mathrm{D}$ ao angulo opposto a linha $\mathrm{DC}$, e o lado $\mathrm{AB}$ se divida em tres partes iguaes nos pontos E, F, e por estes pontos de divizaõ se lance à linha DC as parallelas EG, $\mathrm{FH}$, e dos pontos $\mathrm{G}, \mathrm{H}$, em que as parallelas cortaõ os lados $\mathrm{AC}, \mathrm{CB}$, se lancem as linhas GD, HD, e a terra ficará dividida nas partes iguaes pedidas AGD, GDHC, $\mathrm{BDH}$ : porque cada um dos dous triangulos $\mathrm{ADG}, \mathrm{BDH}$, será igual à terça parte do triangulo $\mathrm{ABC}$, pois que lançando as rectas $\mathrm{CE}, \mathrm{CF}$, o triangulo $\mathrm{ADG}$ he igual ao triangulo $\mathrm{AEC}$, que he a terça parte do proposto $\mathrm{ABC}$, e da mesma sorte o triangulo $\mathrm{BDH}$ he igual ao triangulo $\mathrm{BFC}$, que he tambem o terço do proposto $\mathrm{ABC}$ (Fortes, 1728, p. 146-147).

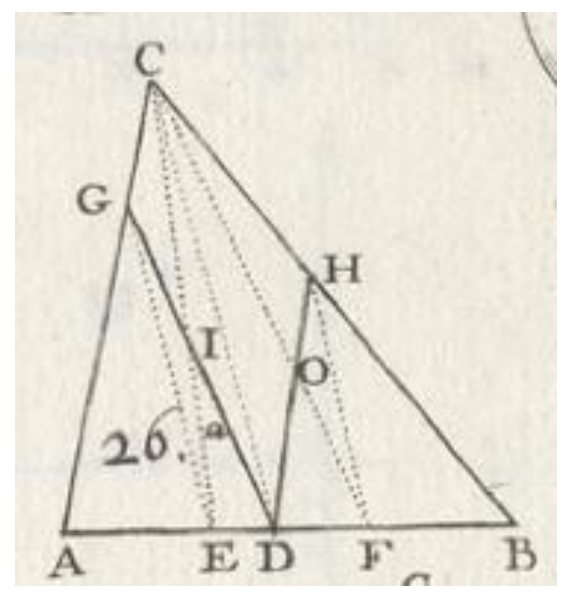

Figura 10 - Divisão de triângulo em partes iguais.

Fonte: Fortes (1728, p. 543).

Fortes ainda descreve, na sequência, duas demonstrações baseadas em semelhança de triângulos para validar a resolução proposta. A bem da verdade, todos os problemas lançados nesse capítulo são acompanhados de demonstrações matemáticas. Especificamente quanto ao desenho, interessante ainda chamar atenção, no Livro II, para o conteúdo apresentado no capítulo XII, que trata Do aumento, deminuiçaõ e reducçaõ, ou Metamorphose das figuras. Além de questões referentes à ampliação, redução e equivalência de áreas, a construção de meia, terceira e quarta proporcionais é também abordada. É o desenho, tomado como conhecimento de base, que sustenta a resolução dos problemas propostos, tal como se pode perceber no Problema II, em que se propõe Fazer hum quadrado igual a hum circulo dado:

Seja dado o circulo $\mathrm{ABG}$, e se quer fazer hum quadrado seu igual: divida-se o diametro $\mathrm{AB}$ em sete partes iguaes, e se produza para $\mathrm{C}$, de sorte, que a linha $\mathrm{BC}$ seja igual a onze dessas partes; e a linha DC se divida no meio pelo ponto $\mathrm{E}$, e desse ponto como centro, e com o intervallo EC, ou ED, se descreva o semicirculo DFC, e do ponto B se lance huma perpendicular (que por inadvertencia naõ vay na figura) the encontrar com a circunferencia, e será o lado do quadrado pedido (Fortes, 1728, p. 206). 
DOI: http://dx.doi.org/10.20396/zet.v26i3.8649929

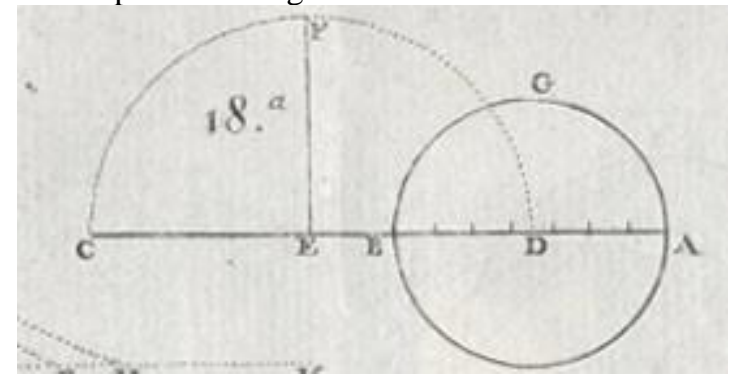

Figura 11 - Traçado de um quadrado equivalente a um círculo dado.

Fonte: Fortes (1728, p. 545).

Ou no problema VIII, em que se pede Entre duas linhas dadas achar huma meia proporcional:

(...) As duas linhas dadas se ajuntem em huma só linha recta, notando o ponto da sua juncçaõ, e a toda se divida pelo meio, para sobre ella descrever hum semicirculo, e do ponto da junçaõ se levante huma perpendicular até encontrar a circunferencia do semicirculo; e esta será a meia proporcional buscada.

Sejaõ as duas linhas dadas DC, CF postas na mesma linha recta DF, e esta toda se divida pelo meio no ponto $\mathrm{E}$, e se descreva o semicirculo DIF, e do ponto $\mathrm{C}$ da juncçaõ das duas linhas, se levante a perpendicular CI, que será a meia proporcional buscada entre as duas linhas DC, CF; e será DC para CI, como CI para CF (Fortes, 1728, p. 211-212).

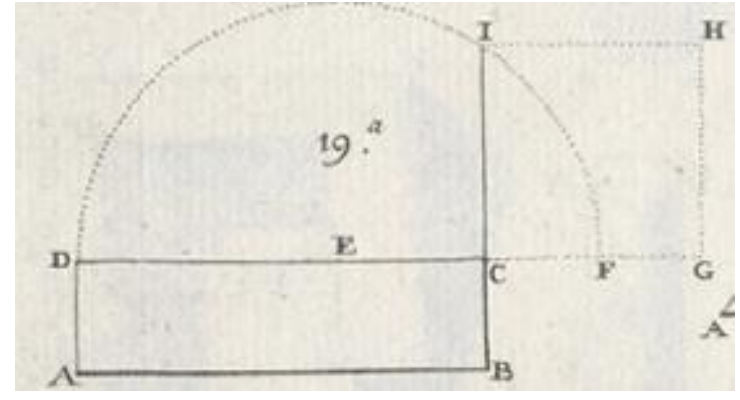

Figura 12 - Traçado de uma meia proporcional entre duas linhas.

Fonte: Fortes (1728, p. 545).

Por fim, no livro III, da estereometria, é possível encontrar um amplo estudo acerca das definições e medida de solidez (volume) de figuras tridimensionais, tais como pirâmides, prismas, poliedros, esferas, cones e cilindros. Interessa aqui, particularmente, o capítulo VIII, que trata da Construcçaõ dos corpos regulares. Toda a parte de construção de sólidos é explorada nesta seção. Vejamos como Fortes propõe, no Problema III, Fazer hum octaedro:

Para fazer hum octaedro, sobre huma linha qualquer, se fassaõ tres triangulos equilateros, como sobre a linha $\mathrm{AB}$, os tres triangulos equilateros $\mathrm{ACD}, \mathrm{CFG}, \mathrm{FBH}$, e sobre $\mathrm{BH}$, se fará o triangulo equilátero $\mathrm{HBI}$, e sobre $\mathrm{BF}$ o triangulo $\mathrm{FEB}$, e sobre GD o triangulo GDK, e será feito o octaedro que se queria fazer; porque tomando por baze qualquer dos oito triangulos, e ajuntando os mais pelas linhas, que terminaõ as superficies, ficará formado o corpo octaedro (Fortes, 1728, p. 311). 


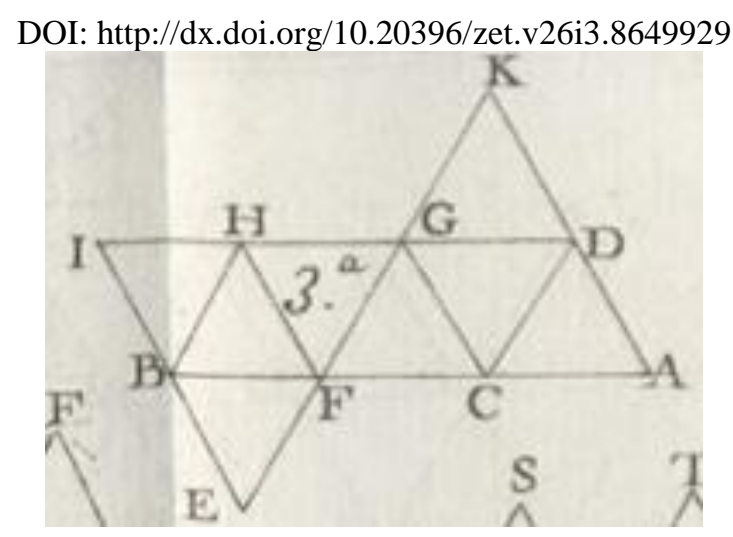

Figura 13 - Construção de um octaedro.

Fonte: Fortes (1728, p. 549).

Da mesma forma, propõe-se a construção do tetraedro, hexaedro, dodecaedro e icosaedro, também de prismas e pirâmides de diferentes bases. Para além disso, interessante notar que o autor dedica todo o capítulo seguinte ao Uso dos instrumentos os mais necessários aos Engenheiros. Explana-se sobre a régua, os diferentes tipos de compasso, petipé, transferidor, prancheta, semicírculo, bússola e nível, arrolando-se uma série de problemas que ilustram seus usos. A prancheta e o semicírculo, em particular, são instrumentos muito semelhantes ao horizonte, descrito por Alberti no seu Descriptio Urbis Romae, assim como são bastante semelhantes os exemplos apresentados acerca de seus usos.

A obra termina com um capítulo dedicado ao Desenho das Plantas Militares. Mas aqui Fortes preocupa-se em estabelecer regras de linhas e cores a serem utilizadas e técnicas de aguada, um colorido monocromático próprio das plantas de arquitetura do período. Questões mais 'práticas', voltadas ao cálculo de distâncias e sua transposição para o papel são abordadas no capítulo anterior, quando se apresentam os instrumentos.

É possível inferir que, assim como o Methodo Lusitânico, o Engenheiro Portuguez figura como um verdadeiro compêndio de desenho. Os conhecimentos necessários são explanados no Tomo I para então abordar-se, especificamente no Tomo II, questões voltadas exclusivamente à arte da guerra e à construção de fortificações. Este segundo tratado está dividido em oito livros que abarcam os seguintes temas, na ordem em que segue: Da Fortificação em geral; Da Fortificação regular; Das obras exteriores; Da delineação do Corpo da Praça, e obras exteriores; Da Fortificação irregular; Da Fortificação effectiva; Da Fortificação offensiva das Praças; Da Fortificação defensiva das Praças; além de um Appendice tratando Das Armas de guerra, e seus usos.

O desenho tem destaque especialmente no Livro II - Da Fortificaçaõ Regular. Seus saberes são aí requeridos na medida em que vão sendo expostos os modos de fortificação abaluartada pelos métodos de autores franceses reconhecidos - Cavalheiro Antonio de Ville, Conde de Pagan, Monsieur de Vauban - e o Método dos três guias. Os demais livros voltamse a uma discussão de caráter teórico-conceitual sobre questões de guerra e fortificação, não propriamente acerca de métodos construtivos. Para exemplificar, vejamos como se dá a Delineaçaõ da Fortificaçaõ regular do cavalheiro Antonio de Ville, apresentada no capítulo I: 
DOI: http://dx.doi.org/10.20396/zet.v26i3.8649929

Divida-se o lado $\mathrm{AB}$ do poligono em seis partes iguaes, e se tome de cada parte huma para demigola, como $\mathrm{AC}, \mathrm{BD}$, e destes pontos se levantem perpendiculares os flancos, e iguaes às demigolas, e se lance a transversal LF, e descrevendo sobre ella um semicirculo, a capital produsida notará na sua circunferencia o ponto aonde se deve formar o angulo flanqueado recto pelas faces tiradas nos pontos L, E, que produzidas daraõ neste exemplo do exagono e nos mais poligonos o flaco segundo $\mathrm{CF}$, que hirá crescendo nas figuras de maior numero de lados (Fortes, $1728 \mathrm{a}^{13}$, p. 60).

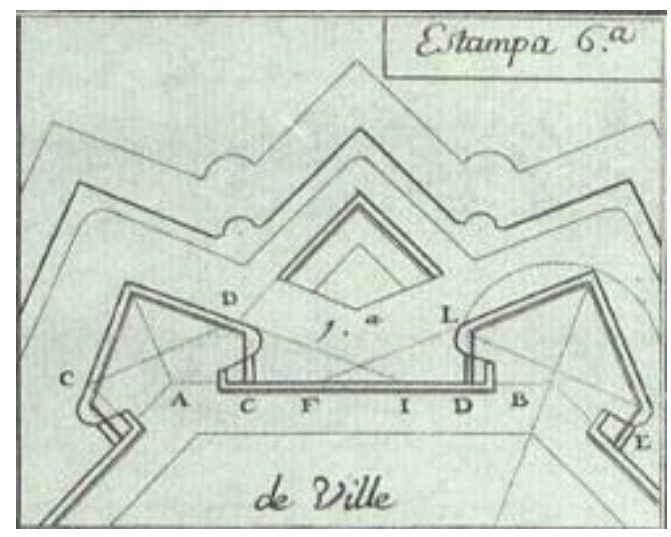

Figura 14 - Delineação de fortificação regular.

Fonte: Fortes (1728a, p. 499).

De forma análoga, os outros métodos de delineação são expostos. Como se vê, tal qual em Dürer e Pimentel, fortificar com Azevedo Fortes exige uma competência específica; exige do engenheiro que desenhe eximiamente para chegar à maior regularidade possível em toda e qualquer obra ideada. Junto a esses tratados, também outros, tais como o francês La science des ingenieurs... (1729), de Belidor, ou o Regras de Desenho para Delineação das Plantas, Perfis e Perspectivas pertencentes à Arquitetura Militar e Civil (1793), de Antônio José Moreira, para citar apenas alguns exemplos, fizeram circular um discurso de exatidão, domínio, controle e certeza sustentado pelo desenho. Por meio do desenho, então, o espaço transformou-se em forma figurada; forma que se quer regular, calculável, visível.

\section{Da captura do traçado}

Esse discurso de regularidade e precisão circulante nos tratados foi, efetivamente, difundido aos militares em formação e capturado e materializado nas inúmeras obras que projetaram e construíram. A série de exercícios realizada pelos alunos de José Antonio Caldas, lente da Aula Militar da Baía, com datas de 1778 e $1779^{14}$, são indicativos dessa apropriação:

\footnotetext{
13 Referencia-se o Tomo II como Fortes (1728a) para diferencia-lo do Tomo I no desenrolar do texto. Entretanto, como os dois tomos fazem parte de uma mesma obra, nas referências ao final do ensaio estarão indicados unicamente como Fortes (1728).

${ }^{14}$ Esses exercícios, em um total de 46, estão hoje localizados no Arquivo Histórico Ultramarino, em Lisboa, Portugal. 18 deles, dentre os quais os que aqui expomos, estão apresentados em Bueno (2011).
} 
DOI: http://dx.doi.org/10.20396/zet.v26i3.8649929

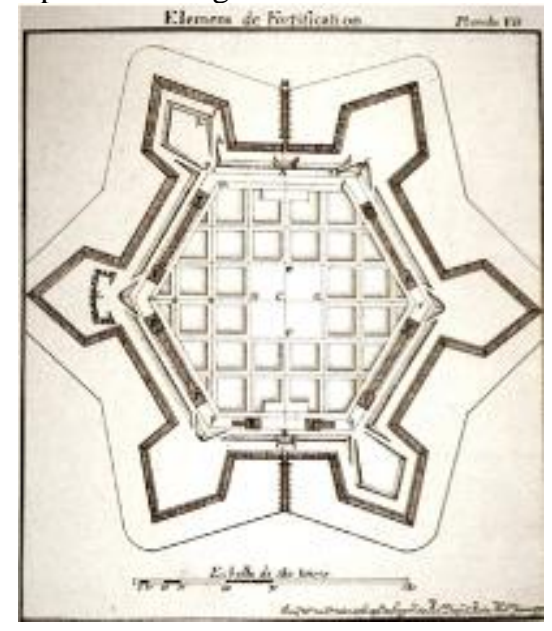

Figura 15 - Exercícios dos alunos da Aula Militar da Bahia sobre elementos da fortificação. Fonte: Bueno (2011).

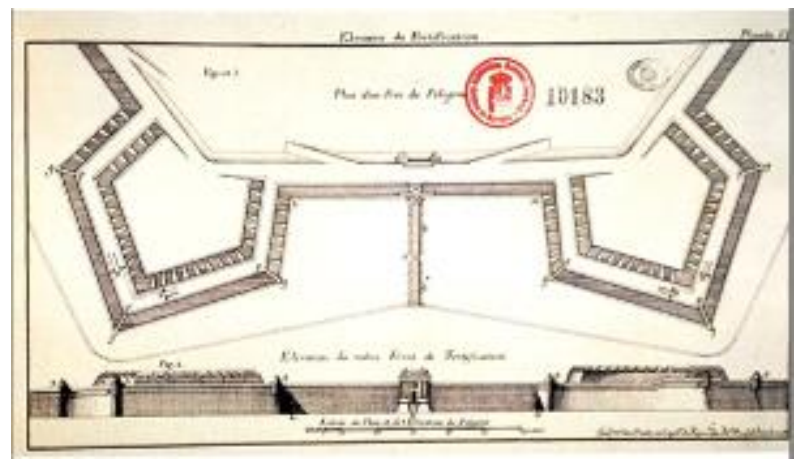

Figura 16 - Exercícios dos alunos da Aula Militar da Bahia sobre elementos da fortificação. Fonte: Bueno (2011).

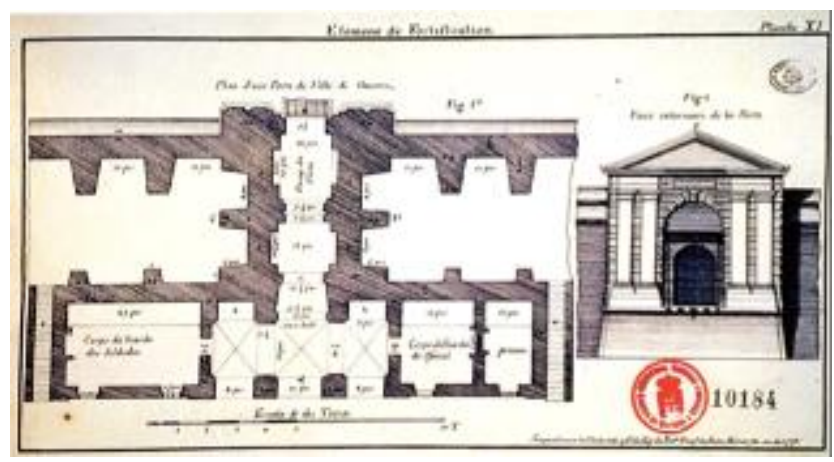

Figura 17 - Exercícios dos alunos da Aula Militar da Bahia sobre elementos da fortificação. Fonte: Bueno (2011). 
DOI: http://dx.doi.org/10.20396/zet.v26i3.8649929

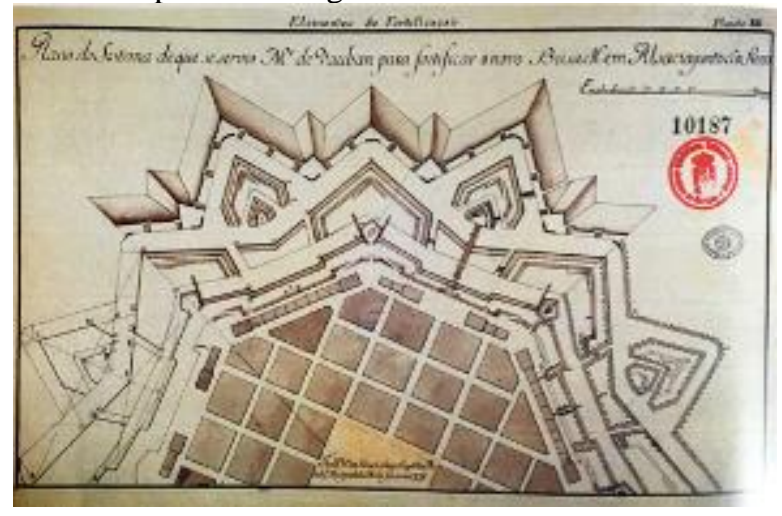

Figura 18 - Exercícios dos alunos da Aula Militar da Bahia sobre elementos da fortificação.

Fonte: Bueno (2011).

Por meio desses exercícios, parece pertinente sugerir que o traçado racional e geometrizado preconizado pelos tratados tenha mesmo se tornado uma prática efetiva do ensino dispensado nas academias militares. Algumas plantas de fortalezas, erguidas em Santa Catarina e no Rio Grande do Sul, outrossim, evidenciam semelhante apoderamento do desenho, tal como é possível perceber no manuscrito Defesa da Ilha de Santa Catarina e do Rio Grande de São Pedro, elaborado entre 1786 e 1789 pelo engenheiro militar José Correia Rangel ${ }^{15}$.

Nesse manuscrito encontra-se o levantamento das fortificações e dos uniformes da Ilha de Santa Catarina (atual Florianópolis) e do Rio Grande de São Pedro (primeira cidade do Rio Grande do Sul). Seu autor, Correia Rangel, provavelmente foi aluno da Aula Militar do Rio de Janeiro, já que sempre há referências à essa praça em sua folha de serviço, tendo formado-se em uma tradição de exigência rigorosa na competência em habilidade gráfica, conforme refletido em seu trabalho (Tonera \& Oliveira, 2015). O referido manuscrito foi realizado dez anos após o desfecho dos episódios de disputa do continente sul-americano entre portugueses e espanhóis, com o objetivo de levantar a situação das defesas da Ilha de Santa Catarina e do Rio Grade de São Pedro, capitanias então portuguesas que haviam se estabelecido e prosperado.

Na Ilha de Santa Catarina, o responsável pelo sistema defensivo foi o Brigadeiro José da Silva Paes (já tendo fundado em 1737 a futura Vila de São Pedro, atual cidade de Rio Grande, no Rio Grande do Sul; e autor de fortes em São Paulo e Rio de Janeiro) ali chegado em 1739, assumindo também seu governo. De acordo com Tonera \& Oliveira (2015, p. 30), suas obras seguiram as orientações técnicas presentes nos tratados de Serrão Pimentel e Azevedo Fortes. Ademais:

15 Conforme Tonera \& Oliveira (2015, p. 14), “o manuscrito original pertence hoje ao acervo do Arquivo Histórico Militar de Lisboa, onde é conhecido informalmente com o nome de Códice de Santa Catarina." O documento, em fac-símile, foi publicado em uma obra organizada por Tonera \& Oliveira, já contendo duas edições, dentre as quais aqui utilizo a segunda, de 2015. Nela, além do fac-símile, são acrescentadas informações sobre as fortificações, panorama histórico de sua criação, e esclarecimentos sobre artilharia e organização das tropas naquele período; além de um glossário, parcialmente ilustrado e uma relação de sites de internet. 
DOI: http://dx.doi.org/10.20396/zet.v26i3.8649929

Azevedo Fortes era engenheiro-mor do Reino quando se iniciaram as obras das fortificações de Silva Paes na Ilha de Santa Catarina, projetos que tiveram a sua análise e aprovação oficial. Aliás, Silva Paes possuía em sua biblioteca particular praticamente todas as obras de Azevedo Fortes, entre outros tratadistas de fortificação da época (Tonera \& Oliveira, 2015, p. 81).

Mas as fortificações em Santa Catarina apresentam peculiaridades por conta das suas variadas condições topográficas locais, o que exigiu uma pluralidade de soluções tipológicas, tanto entre si quanto em relação a outras fortificações espalhadas pelo Brasil:

Nelas não vamos encontrar a solução tradicional do forte regular com baluartes destacados, mas sim terraplenos ou platôs geralmente contidos por trechos descontínuos de muralhas baixas, formando desenhos irregulares, com os canhões atirando quase sempre por sobre os parapeitos dessas muralhas, à barbeta, como se dizia então. Os edifícios não estão enclausurados no interior da fortificação como era comum, mas sim descortinados na paisagem (Tonera \& Oliveira, 2015, p. 31, grifo dos autores).

De fato, isso pode ser constatado se atentarmos para as plantas das quatro principais fortalezas que constituíram o sistema defensivo da Ilha de Santa Catarina: Santa Cruz (iniciada em 1739), construída na Ilha de Anhatomirim; São José da Ponta Grossa (1740), erguida em um pontal de terra ao norte da própria Ilha; Santo Antônio (1740), levantada na Ilha de Ratones Grande; e Nossa Senhora da Conceição, situada na Ilha de Araçatuba.

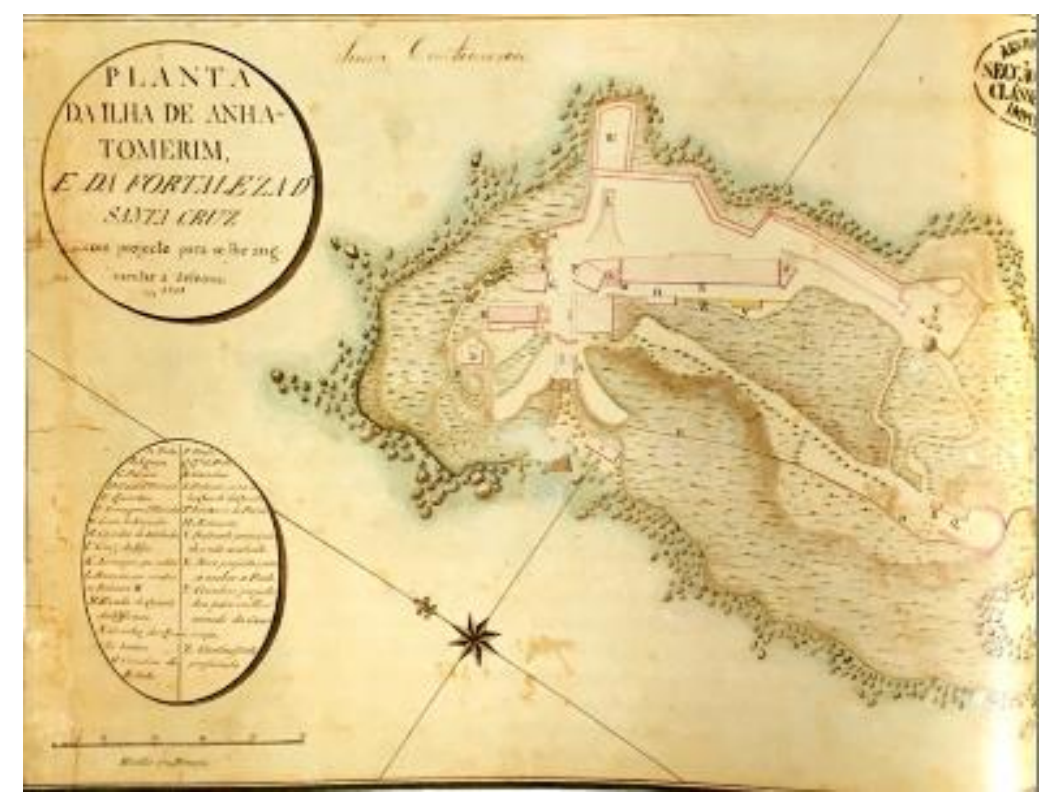

Figura 19 - Planta da Fortaleza de Santa Cruz.

Fonte: Tonera \& Oliveira (2015). 
DOI: http://dx.doi.org/10.20396/zet.v26i3.8649929

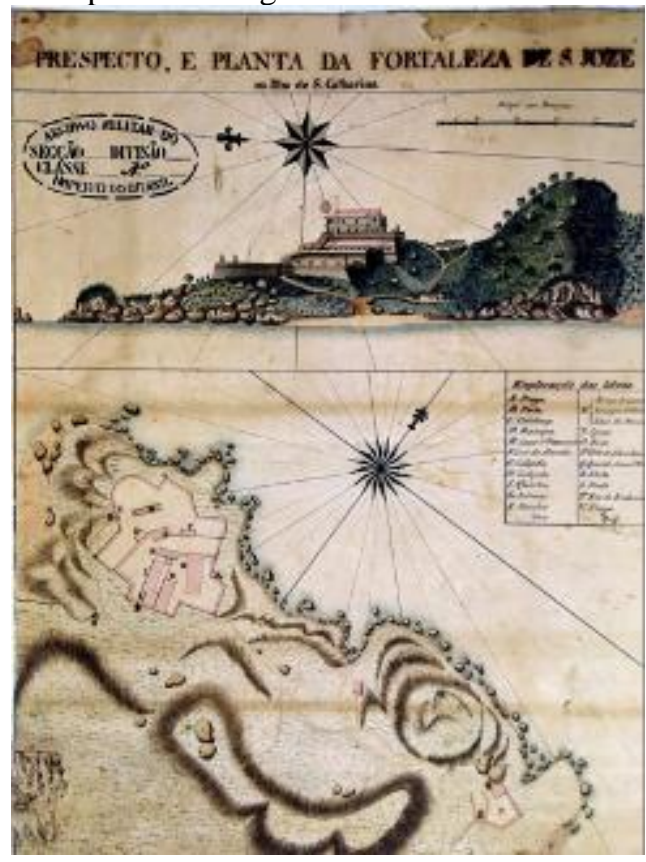

Figura 20 - Planta da Fortaleza de São José da Ponta Grossa. Fonte: Tonera \& Oliveira (2015).

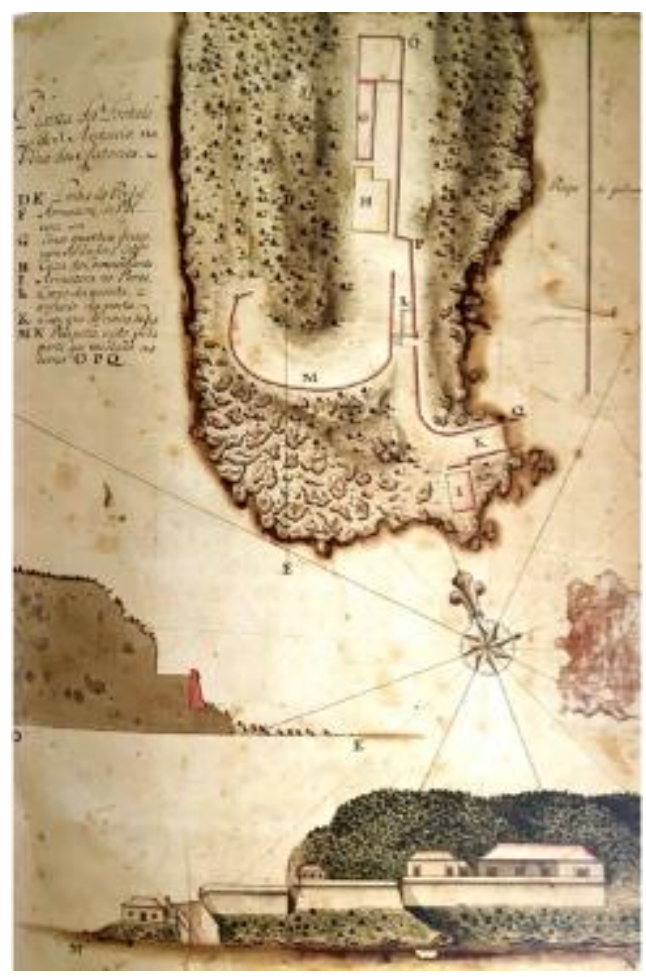

Figura 21 - Planta da Fortaleza de Santo Antonio. Fonte: Tonera \& Oliveira (2015). 
DOI: http://dx.doi.org/10.20396/zet.v26i3.8649929

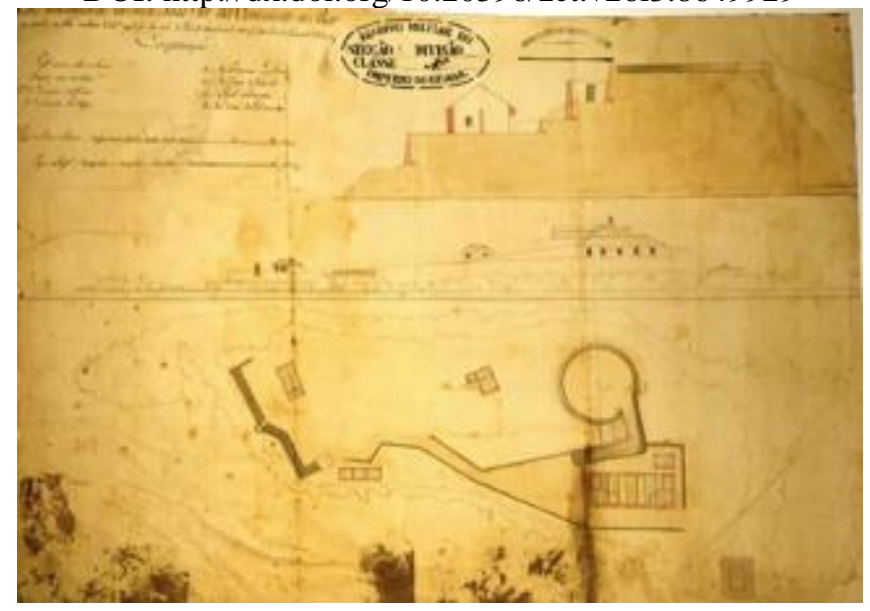

Figura 22 - Planta da Fortaleza de Nossa Senhora da Conceição. Fonte: Tonera \& Oliveira (2015).

Dentre elas, note-se que somente a fortificação da fortaleza de São José é conformada por um polígono irregular. O que não significa que os métodos de Pimentel, Fortes e de outros tratadistas do período tenham sido ignorados. Ao contrário, todos esses autores, ainda que prezando pelo ideário de máxima regularidade, advertiam que eram as condições do terreno o que determinaria o quão próximo desse ideal poder-se-ia chegar. Tanto que outras construções catarinenses, tais como o Forte de Santana (1763), localizado sob a Ponte Hercílio Luz; o Forte de São Francisco Xavier (1763), construído a 2 quilômetros do centro de Florianópolis; e o Forte de São Luís (1771), levantado junto à atual Avenida Beira Mar Norte, a cerca de $4 \mathrm{~km}$ do centro de Florianópolis, por exemplo, apresentam plantas poligonais:

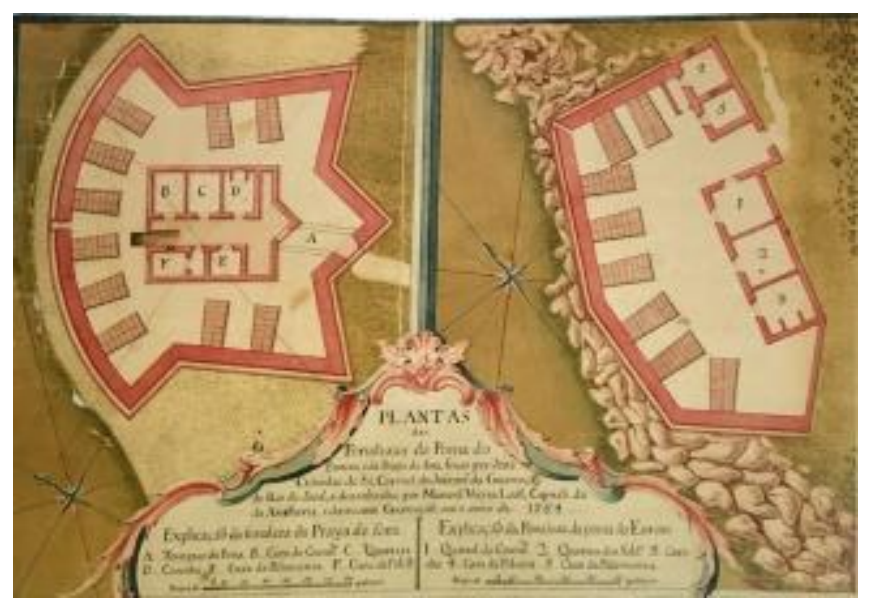

Figura 23 - Plantas da Fortaleza de São Francisco Xavier e de Santana. Fonte: Tonera \& Oliveira (2015). 


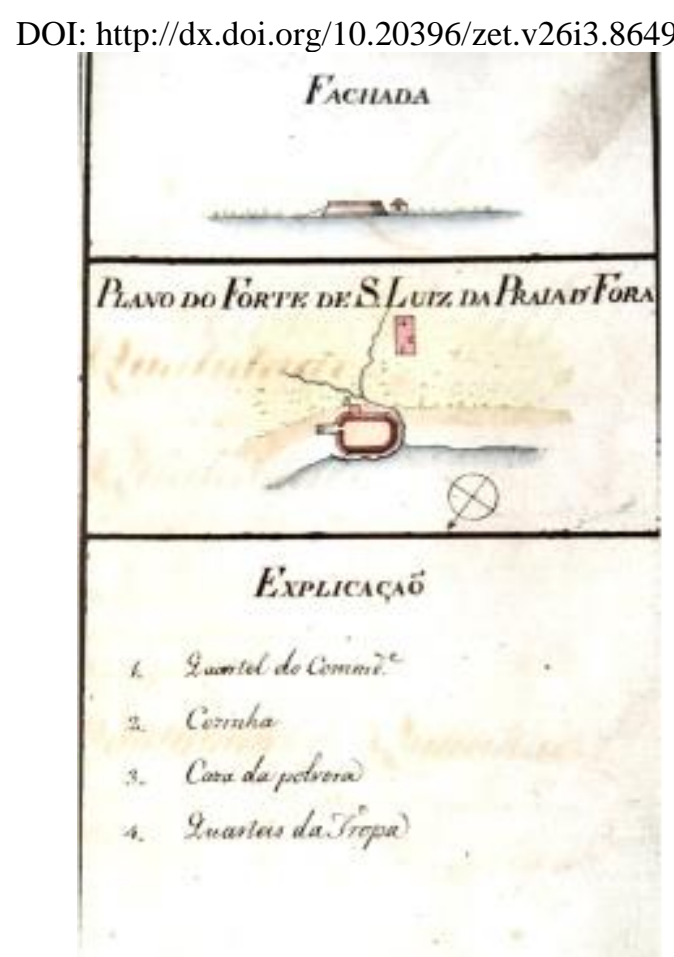

Figura 24 - Plantas da Fortaleza de São Luís.

Fonte: Tonera \& Oliveira (2015).

Interessante ressaltar, mais uma vez, que a busca por regularidade dava-se em todos os âmbitos de atuação militar, incluindo não só as obras defensivas, mas também as civis. A análise de Beatriz Bueno, acerca do projeto do edifício oficial da Caza do Governo de Santa Catarina, na Vila de Desterro (atual Florianópolis), realizado igualmente por José Da Silva Paes, em 1747, demonstra bem essa questão:

No que diz respeito ao senso estético dos engenheiros militares - o correto emprego da métrica, a rigorosa simetria e o apurado manejo do vocabulário de matriz clássica , o melhor exemplo de edifício oficial é o da Caza do Governo de Santa Catarina (...). Esse projeto reúne todos os atributos da boa arquitetura de sua época: ordem, disposição, simetria, eurritmia, decoro e distribuição. Há clara regularidade no ritmo das aberturas da fachada frontal, num compasso de 1:2,5m. O corpo central do frontispício destaca-se do conjunto, ladeado por pilastras e encimado por um frontão triangular. Por outro lado, a sobreposição dos pavimentos evidencia correspondência entre as paredes do andar térreo e do sobrado, demonstrando racionalidade construtiva. A planta organiza-se num retângulo composto de um duplo quadrado, cujo rebatimento da diagonal desenha os limites dos quadrados menores salientes, anexoa, nos quais se inserem a cozinha e o palheiro no térreo, a copa e a casa do fogo no sobrado. Rigorosa disciplina geométrica preside o projeto assinado pelo célebre engenheiro português (Bueno, 2011, p. 264-265, grifos da autora). 
DOI: http://dx.doi.org/10.20396/zet.v26i3.8649929
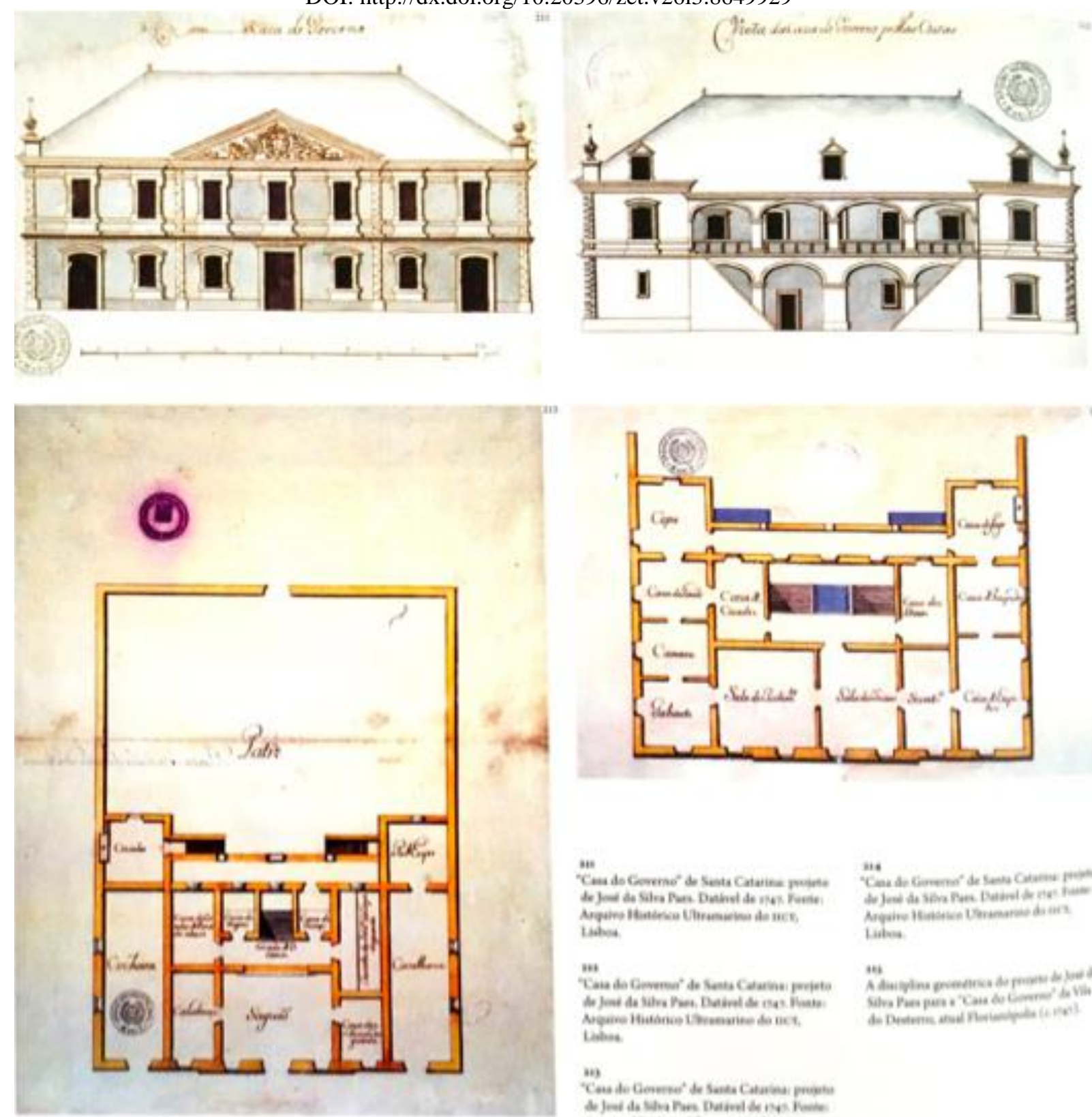

as

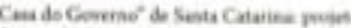

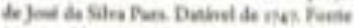

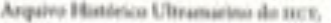
Lises

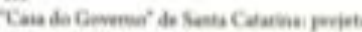

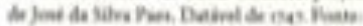

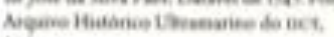
Lishes

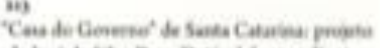

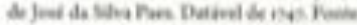

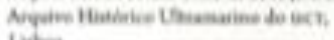

Figura 25 - Plantas da Casa do Governo de Santa Catarina. Fonte: Bueno (2011). 


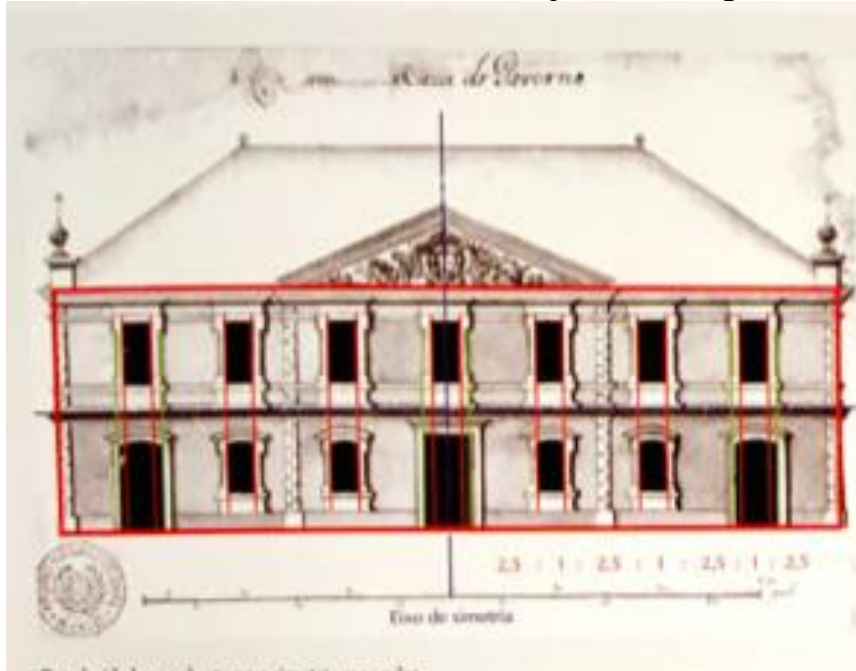

A disciplina geométrica do projeto de José da Silva Paes para a Casa do Governo da Vila do

Desterro, atual Florianópolis (ci747)
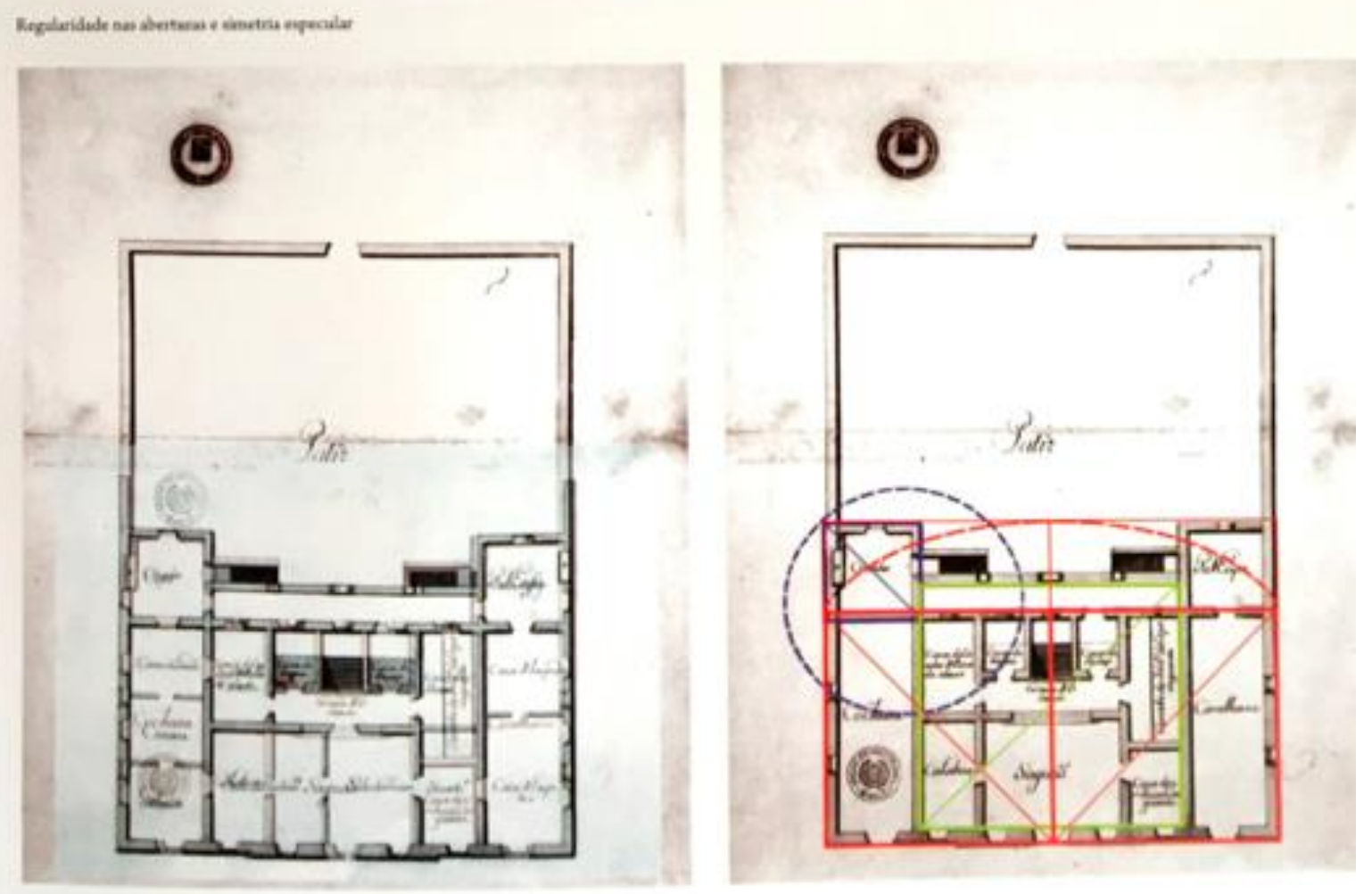

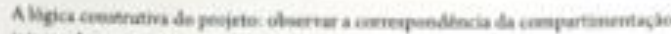

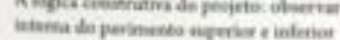

Figura 26 - Plantas da Casa do Governo de Santa Catarina. Fonte: Bueno (2011).

Os fortes do Rio Grande do Sul, por sua vez, indicados no manuscrito de José Correia Rangel, diferentemente de Santa Catarina, comportavam um padrão acentuadamente regular. Isso, certamente, porque as condições do terreno em que foram edificados assim o permitiu. Seus projetos são assinados por diferentes engenheiros, alguns até mesmo de origem espanhola, dado que a região ficou sob domínio da Espanha em alguns períodos específicos durante o século XVIII. O Forte de São José da Barra, construído entre as décadas de 1760 e 1770 , por exemplo, tinha forma quadrada com quatro baluartes pentagonais em seus vértices: 
DOI: http://dx.doi.org/10.20396/zet.v26i3.8649929

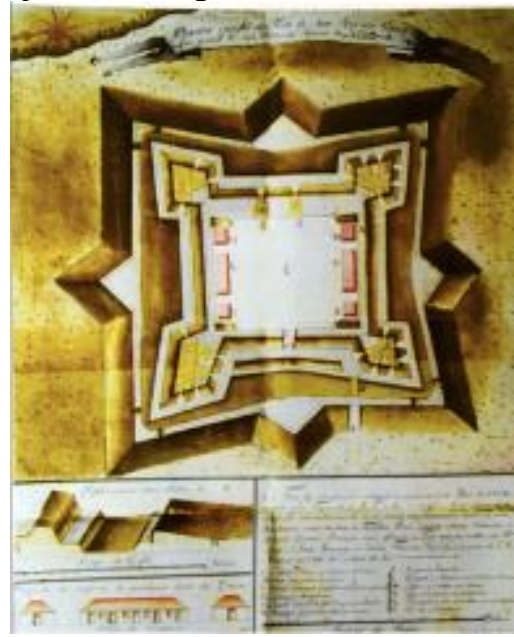

Figura 27 - Planta do Forte São José da Barra.

Fonte: Tonera \& Oliveira (2015).

Já o Forte de São Pedro da Barra, também construído entre as décadas de 1760 e 1770, apresenta um contorno pentagonal quase regular:

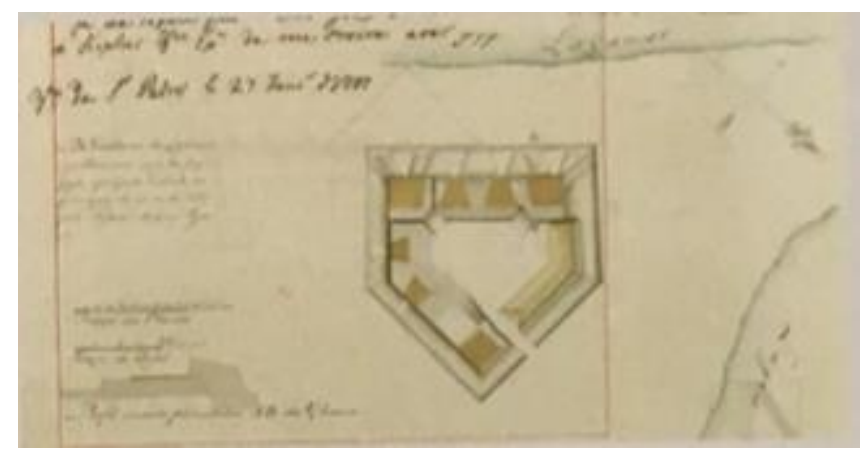

Figura 28 - Planta do Forte São Pedro da Barra.

Fonte: Tonera \& Oliveira (2015).

O Forte do Arroio, construído no mesmo período dos anteriores, compreende uma planta com máxima regularidade, contendo uma estrutura quadrada, em cujos vértices estão acomodados dois baluartes pentagonais, dois meio baluartes, acrescido de um baluarte regular na parte central da cortina, entre dois anteriores.

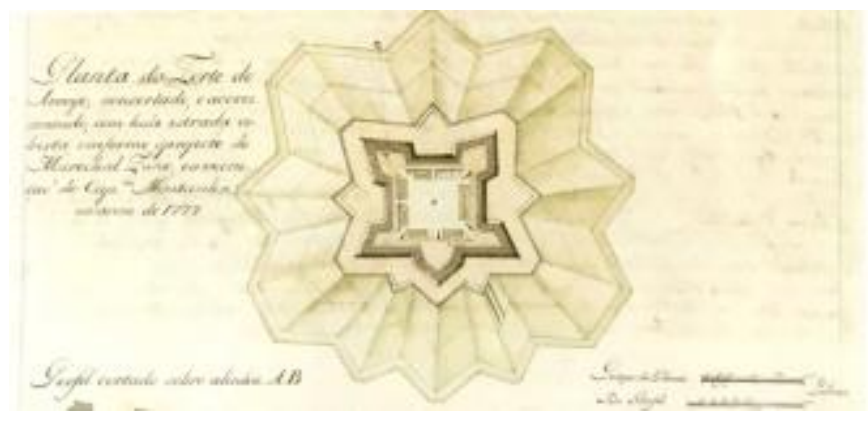

Figura 29 - Planta do Forte do Arroio.

Fonte: Tonera \& Oliveira (2015). 


\section{Dos arremates}

De tudo isso, perceba-se que desenhar é proteger é mesmo um enunciado evidente nos tratados analisados. Entretanto, colado a ele há outro que precisa ser destacado: desenho é poder. Um poder que atualiza o desejo de disciplinamento do espaço, de descrição do mundo, de ordenamento da terra e de vigilância. E se desenho é poder, o é porque cumpre papel de representação. Um papel que se elabora em um jogo de espelhos: ora fazendo as vezes da realidade representada - evocando ausência, ora tornando visível a realidade representada - sugerindo presença.

De qualquer forma, uma relação de representação que, conforme Foucault (2007), traça toda a teoria do signo que inaugurou o pensamento clássico ${ }^{16}$ e que tornou o desenho, doravante, o signo visível de uma realidade reduzida a traços geométricos. Não uma relação que revela "verdadeiramente" uma realidade, mas que antes a constrói. Mesmo quando o desenho pretendia fazer as vezes da realidade apresentada, poderia tranquilamente ser manipulado de forma a prestar-se a variados jogos retóricos; basta considerar os efeitos na "realidade" que uma pequena distorção de longitude em um mapa poderia causar. Em outras palavras, o desenho passou a sublinhar o elemento significante; a dizer o que deveria ser visto. O desenho aí é afirmação; abole o acaso; é a própria "coisa”; o mapa é o território.

O desenho é, portanto, poder; produz poder e é, inversamente, produzido por relações de poder; afinal todo conhecimento produz poder, ao passo que, todo exercício de poder produz conhecimento. Não "O Poder", entendido como soberania do Estado, forma da lei, ou a unidade global de uma dominação. Não algo que estaria situado em um ponto fixado, exercendo-se repressiva e hierarquicamente de 'cima a baixo', entre forte e fraco, dominador e dominado, mas sim:

a multiplicidade de correlações de forças imanentes ao domínio onde se exercem e constitutivas de sua organização; o jogo que, através de lutas e afrontamentos incessantes, as transforma, reforça, inverte; os apoios que tais correlações de forças encontram umas nas outras, formando cadeias ou sistemas, ou ao contrário, as defasagens e contradições que as isolam entre si; enfim as estratégias em que se originam e cujo esboço geral ou cristalização institucional toma corpo nos aparelhos estatais, na formulação da lei, nas hegemonias sociais (Foucault, 2014, p. 100-101).

Assim é que o desenho, - com seus pontos, linhas e códigos -, converteu-se no principal acesso "aos territórios tornados impenetráveis. Uma lógica do traçado se constrói. A superfície do solo se levanta em texto a ser lido" (Flores, 2008, p. 291).

Que a análise desses textos militares, ao buscar apreender como o desenho foi mobilizado nos projetos de fortificação pretendidos e empreendidos possa ajudar, enfim, a compreender que esse saber não pode ser desvinculado de práticas sociais; que foram essas práticas que elegeram seus conteúdos como objeto de ensino; e que são esses conteúdos que vão compor, posteriormente, os currículos escolares.

${ }^{16}$ Para uma discussão detalhada a esse respeito ver Machado (2016). 
DOI: http://dx.doi.org/10.20396/zet.v26i3.8649929

Com o passar do tempo, nas narrativas de Marco, as palavras foram substituindo os objetos e os gestos: no início, exclamações, nomes isolados, verbos secos; depois, torneios de palavras, discursos ramificados e frondosos, metáforas e imagens. $O$ estrangeiro aprendera a falar a língua do imperador, ou o imperador a entender a língua do estrangeiro (Calvino, 2014, p. 41-42).

\section{Referências}

Bélidor, B. F. (1729). La Science des Ingénieurs dans la Conduite des Travoux de Fortifications et d'Architecture Civile. Paris.

Bueno, B. P. S. (2011). Desenho e desígnio: o Brasil dos engenheiros militares (1500-1822). São Paulo: Edusp.

Calvino, I. (2014). As cidades invisíveis. São Paulo: Companhia das letras.

Comenius, J. A. (2002). Didática Magna. Trad. Ivone Castilho Benedetti (2a ed). São Paulo: Martins Fontes.

Dória, R. P. (2004). Entre o Belo e o Útil: manuais e práticas do ensino do desenho no Brasil do século XIX. Tese de Doutorado em Estruturas Ambientais Urbanas. São Paulo: Universidade de São Paulo.

Flores, C. R. (2008). Saber, tecnologia e representação na arte militar do século XVII: a propósito da obra de Luís Serrão Pimentel. Educação Matemática e Pesquisa, São Paulo, 10(2), 279-293.

Fortes, M. A. (1728). O engenheiro portuguez. Lisboa: Officinas Manoel Fernandes da Costa.

Foucault, M. (2010). Microfísica do Poder. Rio de Janeiro: Edições Graal.

Foucault, M. (2014). História da sexualidade I: a vontade de saber. São Paulo: Paz e Terra.

Dürer, A. (2004). Tratado de arquitectura y urbanismo militar. Madri: Akal.

Machado, R. B. (2016). Cartografia, Saber, Poder: Da emergência do desenho como disciplina escolar. Tese de Doutorado em Educação Científica e Tecnológica. Florianópolis: Universidade Federal de Santa Catarina.

Moreira, A. J. (1793). Regras de desenho para planificação das plantas, perfis e perspectiva. Lisboa: Typographia de João Antonio da Silva.

Pimentel, L. S. (1680). Método Lusitânico de Desenhar as Fortificações das Praças Regulares e Irregulares. Lisboa, Impressão de Antonio Craeseeck de Mello Impressor de S. Alteza.

Soromenho, M. (1991). Manuel Pinto de Vilalobos: da Engenharia Militar à Arquitectura. Dissertação de Mestrado em História da Arte. Lisboa: Universidade Nova de Lisboa.

Tonera, R.; Oiveira, M. M. de. (2015). As defesas da Ilha de Santa Catarina e do Rio Grande de São Pedro em 1786 de José Correia Rangel. (2a ed). Florianópolis: Ed. da UFSC.

Trinchão, G. M. C. (2008). O desenho como objeto de ensino: história de uma disciplina a partir dos livros didáticos luso-brasileiros oitocentistas. Tese de Doutorado em Educação. São Leopoldo: Universidade do Vale do Rio Sinos. 